\title{
Influence of SPV Installations on the Thermal Character of the Urban Milieu
}

\author{
Khushal Matai ${ }^{D}$ \\ School of Planning and Architecture, New Delhi 110002, India; arkhushal@live.com; Tel.: +91-9983-45-4645
}

Received: 3 April 2020; Accepted: 15 September 2020; Published: 18 September 2020

\begin{abstract}
The solar photovoltaic (SPV) market is growing at a rapid pace with ambitious targets being set worldwide. India is not far behind with an overall solar target of 100 gigawatts (GW) to be achieved by 2022, out of which 40 gigawatts is to be achieved by solar rooftop. Additionally, the depleting non-renewable energy sources and the extensive pollution being done by the aforementioned sources are fueling the renewable energy drive. The threat of climate change, which is fast becoming a reality with effects seen globally, is another contributing factor. The effect of SPV installations on the temperature profiles of their surroundings and the urban thermal environment (UTE) is being studied at a global level, which has arrived at contradictory results, positive as well as negative. However, no such study has been done in the Indian context, which is crucial considering the country's targets for rooftop installation specifically. The thermal environment of the vicinity is affected by the installations, as seen in the various global studies; the question is how this heat-energy balance is occurring in the Indian context. This review paper looks critically at studies focusing on the relation between SPV installation and the urban heat island (UHI) effect. It is a compilation and analysis of 22 different studies done so far at the global level to gain a thorough understanding of the diverse results. In conclusion, this review highlights the absence of any comprehensive study on the interaction of SPV installations with the built environment at a micro-level and establishes the need for region-based complete studies on the thermal behavior of SPV technology.
\end{abstract}

Keywords: SPV installations; UTE; UHI; heat transfer through SPV; built environment

\section{Introduction}

Solar energy has been hailed as a savior as the world moves rapidly toward a fossil-fuel-less future. The development of large scale solar power plants is taking place at a rapid rate. As we try to shift from the non-renewable energy, new and innovative solutions are being developed that harness the power of the sun, wind, biomass, and ocean, to name a few. In this rat race, there has been little focus on the probable negative effects of these relatively new and rapidly evolving technologies, which could lead to unprecedented repercussions on temperatures in the urban milieu. Solar farms and rooftop installations are the major sources to harness solar energy. Very few studies shed light on the effect of solar energy on the localized urban thermal environment (UTE). Most of the solar photovoltaic (SPV) installations are land-based, which changes the surface characteristics of the land, and understanding these changes is difficult as they vary depending on size, type, and location of the SPV installations [1]. Additionally, the environmental impacts of a solar power plant change, depending on its location in different climatic zones. There are many pieces of research providing a fair understanding of carbon emissions during the manufacturing and life cycle of solar photovoltaic panels, whereas the environmental effects post-installation and during the operational phase have not been researched in detail. Turney, based on the observation, stated that potential change in surface albedo and surface energy flow due to SPV installations is unknown. Furthermore, the author suggested that in-depth research and observation is necessary to identify the changes in local climate [2]. Materials used in the 
urban fabric critically influence its thermal environment. The material's reflectivity and absorptivity are assessed by its albedo and emissivity, the higher the albedo, the higher the reflectivity of long- and shortwave radiation [3]. However, due to the paucity of data, a specific relation between albedo change and urban heating needs further exploration. SPV technology deployment at a rapid rate without understanding its effect on the microclimate and carbon cycle is unwise [4]. Therefore, a review of the research done regarding the relationship between the solar photovoltaic panel installations and their impact on the thermal environment of the surroundings is important.

\section{Urban Thermal Environment (UTE)}

Human activities influence the climate and atmospheric composition at the local level, regional and global scale. The UTE embodies the inadvertent modification in the microclimate of the region. Urban development is capable of modifying the geomorphology of the landscape and altering the soil profiles and the hydrology of the area. The annual mean air temperature of a city with one million or more population can be $1-3^{\circ} \mathrm{C}$ more than its surroundings [5], and this temperature variance can be as much as $12{ }^{\circ} \mathrm{C}$ on a clear, calm night. This effect will also be evident in smaller cities and towns, although it will be lesser due to the city size. Elevated temperatures, particularly during the summer, can affect a community's environment and quality of life. Such changes can also have significant impacts beyond microclimate, counting those on energy use, health, and economics, and, consequently, can turn into a reason for national concern.

\subsection{Land-Atmosphere Interface in Urban Areas}

In summers, the solar insolation can result in the heating of dry, exposed urban surfaces to temperatures of $27-50{ }^{\circ} \mathrm{C}$ hotter than the air [6], whereas the rural areas with shaded and moist surfaces remain close to the air temperatures. The warming of air is not an isolated event and happens in layers over the urban area.

\subsubsection{Urban Boundary Layer}

The envelope of air, which remains $1-2 \mathrm{~km}$ deep by midday but reduces to approximately a hundred meters at night [5], is the urban boundary layer. The anthropogenic heating of the environment extends into this layer through convergence of sensible heat plumes from the local areas and the entrainment of the warmer air from above. This layer extends up to the point where urban landscapes are incapable of influencing the atmosphere.

\subsubsection{Urban Canopy Layer}

This layer exists below the mean roof layer, i.e., below the treetops and roofs. It is a manifestation of the surface energy balance that impacts the air volume inside the canyon, predominantly via sensible heat transfer from the surface into the canyon [7]. Since this is the zone occupied by the population, it affects them the most. Usually, this layer is more prominent during the daytime due to the solar heating, which creates large differences between the moist surfaces of the open areas and dry surfaces of the paved areas.

\subsection{Factors Affecting the UTE}

A UTE is broadly impacted by the physical parameters or urban forms that modify the surface properties of the surroundings and anthropogenic emissions [5].

There are various parameters of an urban form that affect the UTE (Figure 1a). The materials have unique properties of reflecting, absorbing, and transmitting heat. Solar energy is constituted of ultraviolet, visible light, and infrared energy. Solar reflectance, or albedo, is the percentage of the solar energy reflected by a surface [8]. Much of the sun's energy is found in the visible wavelengths, thus solar reflectance is co-related with a material's color. Darker surfaces tend to have lower solar 
reflectance values than lighter surfaces. Urban areas have surface materials with lower albedo, such as roofing and paving. Thus, solar energy is reflected less and absorbed more, which increases surface temperatures and contributes to the development of surface and atmospheric urban heat islands (UHIs).
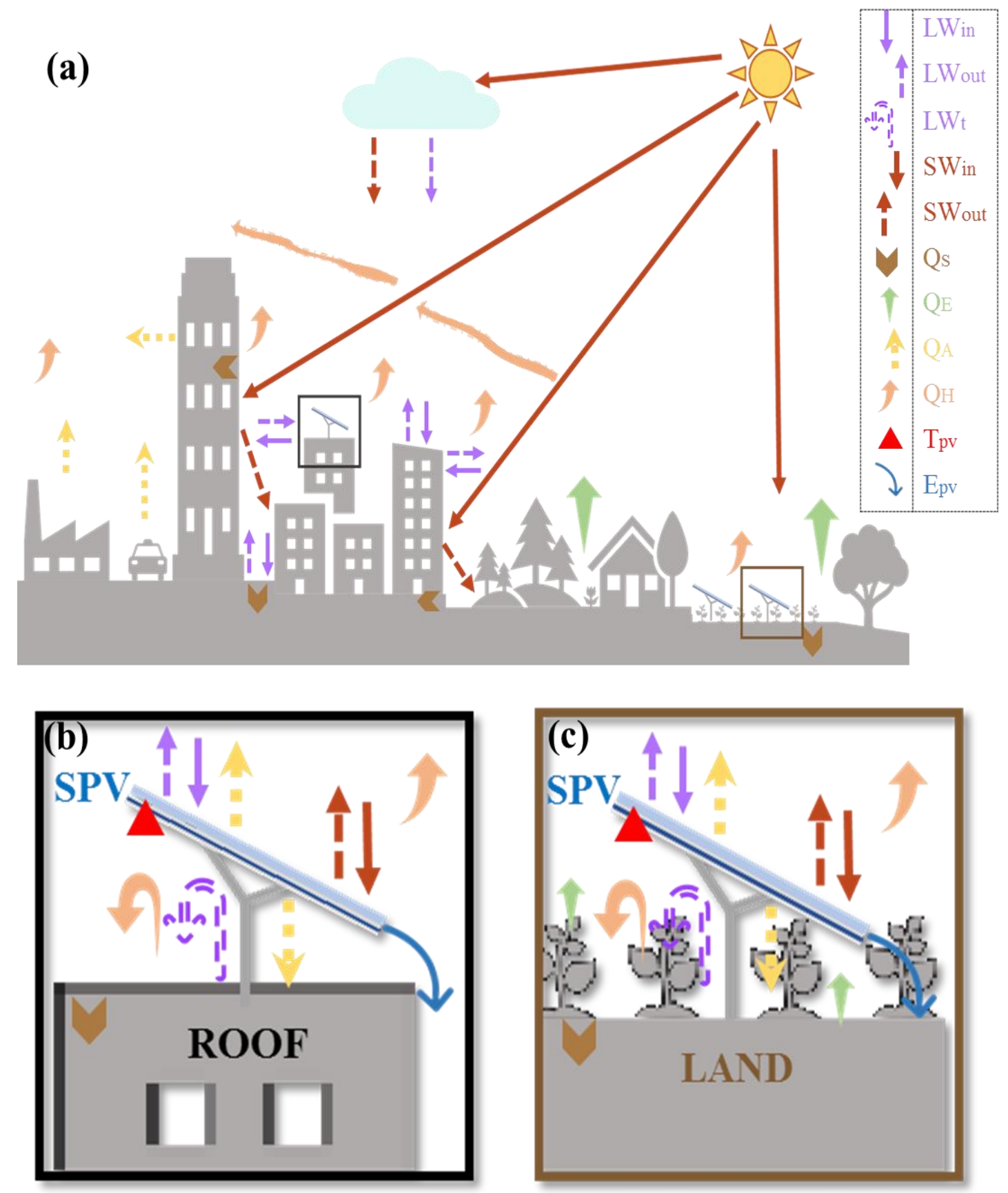

Figure 1. Illustration of energy exchange alteration modes: (a) Urban Surface Energy Budget; (b) Rooftop solar photovoltaic (SPV) panel energy exchange diagram; (c) Land-based SPV panel energy exchange diagram.

Thermal emissivity also plays a role in the material's surface temperature [9]. It is the measure of a surface's capacity to release heat or emanate longwave (infrared) radiation; hence, surfaces with higher emittance values will stay cooler as they will emit heat readily. Reflective roofs are found to be better in reflecting a significant portion of solar radiation even in atmospheres with substantial aerosol loading [10]. 
Another important property that influences the UTE is a material's heat capacity, which refers to its ability to store heat [11]. Some materials such as steel and stone have higher heat capacities than sand. As a result, cities store as much as twice the heat of the rural areas [12].

The urban geometry of a city represents the sizes and layout of buildings inside a city. It influences energy absorption, wind flow, and a surface's capability to emit longwave radiation back into the atmosphere [13]. The sunlight is reflected back multiple times in the urban canyon, which further lowers the city's overall albedo and can increase temperatures [13]. The two-dimensional cross section of the urban canyons is also explained through a dimensionless ratio of the height of the buildings to the width of the street [5].

The anthropogenic heat release from vehicles, industries, heating and cooling systems increases the ambient air temperature of the UTE, which fuels the need of further cooling of the indoor environment, more heat being ejected into the outdoors and resulting in an endless cycle.

\subsection{Tools to Measure the UTE}

There are a variety of methods to study the UTE with clearly stated scientific and/or applied objectives, which stipulate the properties and processes of interest (e.g., air temperature), domain/physical extent of the system being studied, and strategy to capture the multidimensional (horizontal, vertical, temporal) variations within the systems. Considering that the UTE is an amalgamation of complex and often conflicting processes, it is critical to understand that the intention is to isolate and then understand the effect of various processes on the overall environment. Therefore, any research must control the extraneous effects that are not under the study.

The techniques to study the UTE can be divided into two groups, observational approach and simulation approach [14]. Observational approaches are field measurements, thermal remote sensing or small-scale modeling (models built for wind tunnel tests or measurements in the outdoor environment), whereas simulation approaches can be either energy balance models or numerical studies using computational fluid dynamics (CFD) (Figure 2).

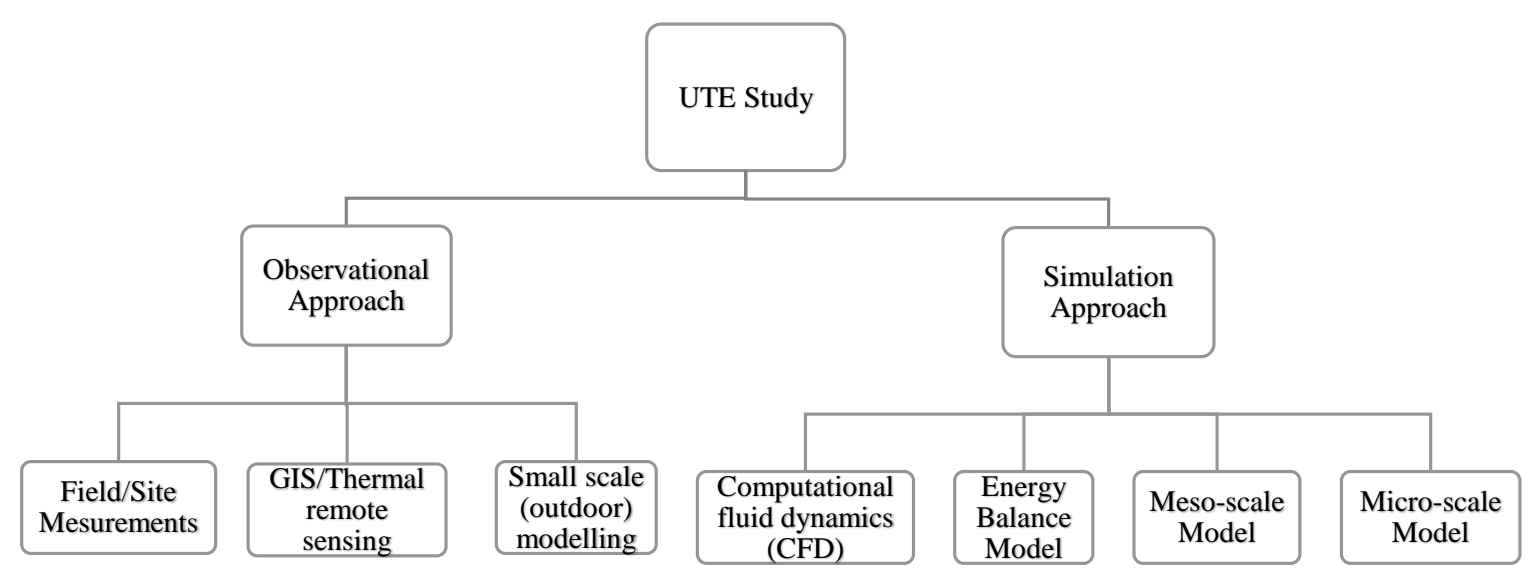

Figure 2. Different approaches for an urban thermal environment (UTE) study.

Systematic record of measurements on a site through instruments is the time-tested approach. In the field measurement approach, the near-surface temperature pattern in an urban area is compared with a rural area in general [15]. This involves the analysis of statistics on urban-rural differences based on fixed or mobile stations. Howard first used field measurement to study the UHI effect for the city of London in 1818 [16]. Since then, field studies have been conducted in various cities to find spatial distribution and intensity of UHI effects.

With the advancement in measurement equipment, other parameters such as air velocity, turbulence fluctuations, and pollution concentration are also being measured to discover interrelationships with heating of the UTE. Despite this, it must be noted that field measurements, 
as an autonomous method, have several limitations. The installation of measurement devices around a place is a costly and complex task. Additionally, only a certain number of parameters can be measured simultaneously due to limited stationery stations. Eventually, data analysis is the weakest point of this technique. Even after gathering satisfactory data, consistent generalizations cannot be made with simple correlations between measurements and UTE characteristics, because of the numerous parameters [17] that can affect the temperatures.

The simplest method to evaluate an urban climate over time is to use a conventional weather station to gather weather data over decades. The station can observe precipitation, humidity, wind, temperature, etc., and the data can be compared to other sites to establish comparisons [5]. Another way to collect data is to move the equipment around the study area. Mobile transverse involves taking readings using a simple set of weather instruments by traveling on a pre-set path throughout a region, stopping at representative locations [18].

Remote sensing techniques help in measuring the resultant surface temperature data, which comprise the effects of surface radiative and thermodynamic properties like surface moisture, surface emissivity, surface albedo, the irradiative input at the surface, and the effects of the near-surface atmosphere, besides the turbulent transfer from the surface [14]. The inverse of Planck's law (the energy emitted by a surface is directly related to its temperature) is used to develop blackbody/brightness temperatures from top of atmosphere (TOA) radiances [19]. These calculations are complicated because natural surfaces do not behave like a blackbody. The essential technical concern in this concept is that the surface temperature measured by the sensors only links to the spatial patterns of upward thermal radiance received by the remote sensor [20]. However, the surface temperature data differ from the atmospheric air temperature data. This means that observed surface temperature can differ significantly from the ambient air temperature inside the street canyons [14]. Satellite techniques have been used since 1970 for investigating urban heating; however, the technology is continuously evolving with better sensor resolution, global coverage, satellite availability, and better understanding of the scientific processes [19].

There has been extensive use of the energy balance model in UHI research [21]. Computational fluid dynamics (CFD) has been highlighted as a useful tool for coupling temperature and velocity fields, but it requires high-resolution modeling of urban areas, the knowledge of relevant boundary conditions, and sufficient computational resources for the simulations [22].

The studies are done through the climate data modeling, use of GIS for thermal mapping, and on-site measurements that have been reviewed here. Meteorological models were used by Taha to understand the potential effect of SPV installations on the atmosphere [23], whereas another study investigated the effect of large scale solar panel installations on the global climate with the help of the Community Climate System Model version 4 (CCSM4) [24]. The review suggested that remote sensing methods could be used to identify land-cover changes due to large scale solar installations [25]. The vertical and lateral extent of the heat island around SPV installations can be understood via remote sensing and ground measurements [26]. Matai used thermal imagery to identify a rise in the land surface temperature of land-based SPV installations regarding their surroundings [27]. An on-site study done on three sites found nighttime temperatures on SPV plants $3-4{ }^{\circ} \mathrm{C}$ higher than those on wildlands [26].

\subsection{Summary}

The UTE with its impacting factors is becoming a significant aspect of climate change mitigation and adaptation as global populations urbanize, especially in the developing countries that lie in the warm climatic belts. At the global level, all major stakeholders are drawing attention to the challenge of urbanization and the environmental stresses in cities, which affect the urban poor more. They also emphasize the need for further research on urban systems and climate change to enable integrated urban planning for mitigation. The United Nations Framework Convention on Climate Change (UNFCCC) provides the momentum for most policy action while United Nations Environment Programme (UNEP) 
and Intergovernmental Panel on Climate Change (IPCC) lay out the frameworks and an informed basis for policy design. An understanding of current and possible future changes in the evolving UTE is therefore necessary for the planning and developing of adaptation and mitigation strategies.

\section{UTE and Solar Photovoltaic}

Solar photovoltaic installations are increasing at a fast pace. Change in the global climate due to SPV panels is considered negligible when compared with the issues related to fossil fuel consumption. Even if the energy demand of the whole globe is met with SPV panels, there will not be any substantial rise in the global mean temperature. However, changes in the regional climate due to SPV installations will impact some regions much more than the rest [24]. Most of the SPV installations are land based and change the surface characteristics of the land, and understanding these changes is difficult as they fluctuate depending on size, type, and location of the SPV installations [1]. Specifically, SPV installations in sunny regions increase the regional atmospheric heat island effect and localized surface heating, which results in increased energy demand for cooling and therefore decreases the effective net efficiency of the solar installation [28].

Additionally, the environmental impacts of a solar power plant change, depending on its location in different climatic zones. Turney stated that potential change in surface albedo and surface energy flow due to SPV installations is unknown. Furthermore, the author suggested that in-depth research and observation is essential to ascertain the changes in local climate [2].

Cortes et al. emphasized that in clear weather conditions, the cooling effect is greater on the roof surface during daytime due to efficient thermal convection and the greater sky view factor, whereas during nighttime the cooling effect is greater on the wall surface due to the shading effect [29].

SPV deployment at a fast pace without understanding its effect on the microclimate and carbon cycle is unwise [30]. Utility-scale SPV installations may fragment habitat and become barriers in the movement patterns of some fauna [31].

\subsection{Behavior of SPV in Urban Milieu}

The current mainstream SPV technology used to harness solar energy and produce electricity is crystalline-based. The major constraint of this technology is solar conversion efficiency (effpv). According to the National Renewable Energy Laboratory (NREL), based on different laboratories globally, the effpv of the monocrystalline, polycrystalline, and thin-film under standard test conditions (STCs) are $24.7 \%, 20.3 \%$, and $19.9 \%$, respectively [32]. This gets further reduced with a rise in the temperature of the SPV cell and panel, respectively. There are numerous studies on the effect of temperature on the performance of SPV installations. Researches discuss the temperature of the back surface, incoming and outgoing radiation on and from the surface of the SPV panel. However, there is a paucity of data on total heat influx and outflux around the SPV installations. To maximize the absorption of solar radiation falling on the SPV module, cells have a textured surface and antireflective coating. The reflectivity for raw silicon, which is $30 \%$, is reduced to $1 \%$. However, post-installation albedo variation is $5-10 \%$ due to varying site conditions (e.g., tilt angle and orientation) [33].

On-site observations proved that the increase in temperature of the SPV panel increases the short circuit current and decreases the voltage substantially [34]. Opaque crystalline SPV panels have an albedo $(\alpha)$ of 0.05 [28]. Therefore, the crystalline SPV panel has 85-95\% of solar absorptance. Depending on the conversion efficiency, SPV panels convert 13-20\% into electricity and rest all gets converted into heat (Figure 3). This heat gets transferred into the surroundings through conduction, convection, and radiation. The overall energy exchange of an SPV panel in the working environment is shown in Figure 1b,c. 


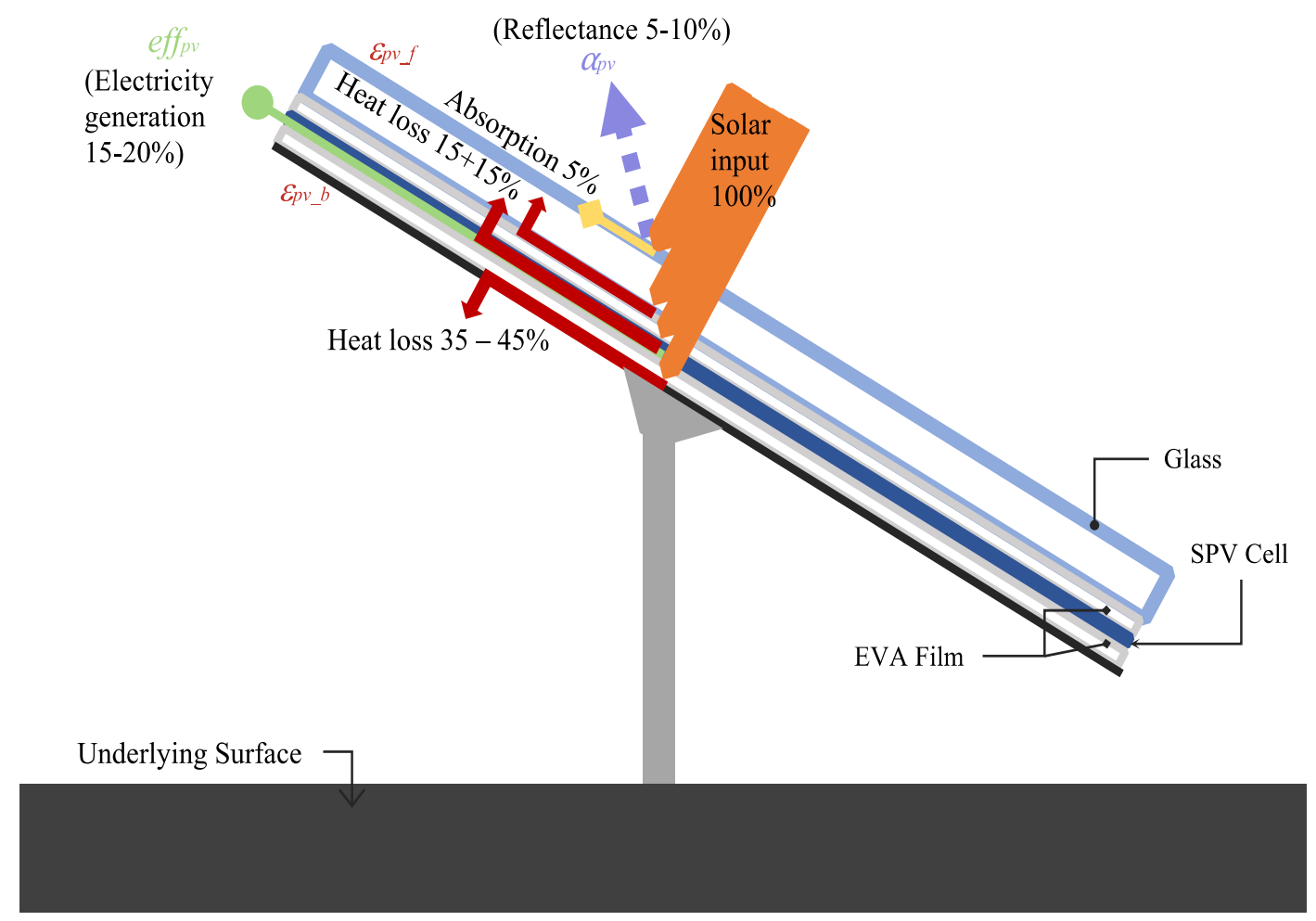

Figure 3. Heat transfer through an SPV module.

\subsection{Modified Surface Properties Due to Materials}

Materials used in the urban fabric critically influence the surrounding thermal environment. SPV installations decrease the albedo and alter the absorption properties of the earth's surface, which impacts the global and regional climate [35]. Any material's reflectivity and absorptivity are assessed by its albedo and emissivity, so the surface reflectivity of long- and shortwave radiation increases with rising albedo levels [3]. Nemet reviewed and suspected an increase in global temperatures due to increased net radiative forcing caused by low albedo and light-absorbing dark-colored SPV installations on the earth's surface. Furthermore, the author analyzed the concerns about increased net radiative forcing for seven locations via equations for different parameters and found them insubstantial in comparison to emissions due to continued use of fossil fuels. However, the albedo effect can change with reduced efficiency and reflectance of SPV panels; SPV installations on highly reflective surfaces can also cause changes in albedo levels [33].

Large scale SPV installations cause a thermal imbalance in microclimate and change the land cover [25]. The exposed surfaces heat more under solar insolation in the buildings with SPV installations. Burg et al. suggest that, in comparison with a white roof, this additional heating of the surface increases the energy demand required for space conditioning in the buildings. Hence, SPV installations should not be done in urban areas, but possibly in the deserts [35]. However, a climate model-based study done for SPV installations over the Mojave Desert highlighted that the afternoon temperature increased by $+0.4{ }^{\circ} \mathrm{C}$ due to the reduction in albedo [36]. Moreover, SPV installations alter the wind movements at both a local and a regional radius of about $300 \mathrm{~km}$ [36].

The dark-colored surfaces of SPV panels with a low albedo increase the global temperature due to increased net radiative forcing. However, the study conducted at seven locations with different parameters found this to be insubstantial due to the miniscule ratio of solar energy usage. Nonetheless, the albedo effect does get amplified as the geographical area of the installations increases [23]. Albedo change can affect some urban areas more than others. Both winters and summers can have a temperature change $\sim 60 \%$ due to variation in albedo [36], which underlines the criticality of unchecked SPV installations being proposed around the world. SPV panels almost double the peak and average 
sensible heat flux compared to unshaded asphalt, thus increasing the temperature levels of the urban milieu [37].

Large scale rooftop SPV installations on a black surface increased daytime sensible heat flux by $\sim 40 \mathrm{~W} / \mathrm{m}^{2}$ in Tokyo [38]. The paper strongly underlined the correlation between the black roofs and the impact so it may be presumed that if photovoltaic (PV) panels are installed on a cool roof or light-colored roofs then the effect could be quite different.

Donovan performed theoretical calculations, assuming similar albedo levels for a land-based SPV installation and the green land underneath it and presumed that the contribution of SPV installations towards urban heating is insignificant [39]. A comparative study of SPV installations over a black roof, green roof, and white roof was done to quantify the heat flux generated in the urban milieu [40]. Simulations of five locations in the USA done using an EnergyPlus building simulation model and weather datasets found a reduction of up to $11 \%$ in daily average sensible heat flux due to SPV installations on black rooftops in the urban environs [40]. In comparison to the black roof, the reduction in the total heat flux was pronounced for white and green roofs [40]. The addition of SPV panels on the black rooftop reduced the summertime heat island impact of a black roof. In contrast, the heat island impact of the white and the green roofs increased upon the addition of SPV panels on the roof [40].

A Hong Kong based study observed year-round increment of 8.3\% in effpv for SPV installations on the green roof then that of bare roof. A Spain-based study focused on the improvement of the SPV system and evaluated SPV installation on both a green roof and a gravel roof. The temperature levels of the module and underlying surface were found to be lower for the green roof than the gravel roof [41]. However, since $\mathrm{T}_{\mathrm{pv}}$ was much less because of the experimental set-up of SPV; therefore, the effect of LWout from roof, covered by SPV was not quantified. Moreover, data collection was restricted to two months (June, July 2013).

Therefore, to achieve more robust and reliable results, the study of large SPV installations for all the seasons with more parameters and data sets needs to be done.

A study conducted on SPV panels as pavement material highlighted a substantial decrease in surface and ambient temperatures up to $-5^{\circ} \mathrm{C}$ and $-2{ }^{\circ} \mathrm{C}$, respectively, compared to the conventional pavements [42].

\subsection{Modified Temperature Profile Due to SPV}

There are diverse hypotheses over the impact of SPV installations on the UTE, ranging from SPV panels reducing the heat absorption of the underlaying surface to them reducing evapotranspiration due to removal of vegetation from SPV plants. SPV panels have little heat capacity and radiate thermal energy quickly into the surrounding, which increases the ambient temperature during the daytime [26]. Additionally, panels hamper the nocturnal cooling of the underlaying surface by trapping longwave radiation [26]. An 18-month-long field study and CFD simulation were conducted to gauge the alteration in the temperature levels at varying height levels above and around land-based SPV installations. The analysis projected a temperature increase of $1.9^{\circ} \mathrm{C}$ higher than the ambient temperature at $2.5 \mathrm{~m}$ above ground level. Additionally, this increased temperature decreases with increasing height and attains equilibrium with the ambient conditions at $300 \mathrm{~m}$ [39].

A study conducted in Paris deduced that the impact of the solar panels on the air temperature is relatively small in winter when the sun is at a lower altitude [43]. SPV installations in dense suburbs of Paris reduced day and nighttime air temperature [43]. Furthermore, besides the reduction in UHIs in summers, solar panels would also reduce the space conditioning demand [43]. However, unlike others, the study implemented both solar thermal and SPV installations in the simulation model [43].

In agreement with the abovementioned authors, another study done for global climate via CCSM4 observed a temperature drop of about $0.26^{\circ} \mathrm{C}$ in urban regions with solar installations [24]. Up to $1{ }^{\circ} \mathrm{C}$ of temperature drop was observed at a hemispherical scale except for a few locations, whereas warming up to $1^{\circ} \mathrm{C}$ was observed in India, eastern Australia, and the west coast of North America. The reason for heating in both India and eastern Australia might be lack of evaporative cooling due 
to a lack of precipitation in both regions [24]. This implies that a regional level study of these three regions is necessary.

Another simulation study, done via the Weather Research Forecasting (WRF) model coupled with the building energy model demonstrated that rooftop SPV installations reduce air conditioning demand during daytime and increase it during nighttime [44]. Moreover, SPV panels decrease the nocturnal cooling of the roof. However, SPV installations are more effective at decreasing nocturnal UHIs, whereas cool roofs effectively mitigate daytime UHIs [44]. In conclusion, the deployment of SPV panels on the rooftop can act as an additional strategy to mitigate UHIs [30].

CFD simulations conducted with on-site data showed that the presence of access roads between SPV installations acts as a cooling zone due to channelized airflow [39]. Therefore, the author hypothesized that the growth in the size of a land-based SPV installation might not affect surrounding temperature levels. However, SPV farm design variations and complications were not considered in simulation and analysis.

\subsection{Effect of SPV Technological Improvements on the UTE}

A meteorological model-based study focusing on potential air temperature effect due to SPV deployment in US cities stated that if SPV reflectivity and conversion efficiency is of $0.08 \%$ and $10 \%$, respectively, then there is no negative impact on urban temperatures. Additionally, SPV panels with a conversion efficiency of more than $10 \%$ provide a cooling effect [23]. However, in this case, the average urban albedo of US cities was selected as 0.18 from the range of $0.15-0.22$. If the urban albedo range shifts to $0.25-0.28$ due to the mass deployment of cool roofs, then an increment in the effpv of $17-20 \%$ will be necessary to reach equilibrium [23].

This is further established by a study conducted in Arizona, which demonstrated that as the conversion efficiency of the SPV increases, it can cause substantial reduction in the cumulative daily sensible heat flux. Additionally, the study underlined the effect of emissivity [45].

Chang et al. highlighted that the magnitude and significance of changes in land surface temperature, humidity, and wind patterns are correlated with the installed capacity of the SPV plant [46].

\section{Conclusions and Future Perspective}

Most of the studies done worldwide have focused on the effect of SPV installations on factors such as air temperature, albedo levels, heat flow, air currents, and sensible heat flux. Based on each study covered in the paper, the varied and confounding inferences about the influence of SPV installation on the urban thermal character were put in tabular form (Table 1).

Table 1. Interpretation of studies done on the relation of SPV installation to the UTE.

\begin{tabular}{cccccc}
\hline Paper & $\begin{array}{c}\text { Tools Use for } \\
\text { Analysis }\end{array}$ & $\begin{array}{c}\text { YES, SPV } \\
\text { Affects the } \\
\text { Urban Milieu }\end{array}$ & $\begin{array}{c}\text { NO, SPV Does } \\
\text { not Affect the } \\
\text { Urban Milieu }\end{array}$ & $\begin{array}{c}\text { Mixed } \\
\text { Results }\end{array}$ & $\begin{array}{c}\text { More Detailed } \\
\text { Studies are } \\
\text { Required }\end{array}$ \\
\hline$[1]$ & $\begin{array}{c}\text { Mathematical } \\
\text { model }\end{array}$ & & $\sqrt{ }$ & $\sqrt{ }$ \\
\hline$[2]$ & Review & $\sqrt{ }$ & $\sqrt{ }$ & $\sqrt{ }$ \\
\hline$[4]$ & Review & $\sqrt{ }$ & $\sqrt{ }$ \\
\hline$[23]$ & $\begin{array}{c}\text { Simulation } \\
\text { model }\end{array}$ & & $\sqrt{ }$ & $\sqrt{ }$ \\
\hline$[24]$ & $\begin{array}{c}\text { Simulation } \\
\text { model }\end{array}$ & & $\sqrt{ }$ & \\
\hline$[25]$ & Remote sensing & & & & \\
\hline
\end{tabular}


Table 1. Cont.

\begin{tabular}{|c|c|c|c|c|c|}
\hline \multirow[b]{2}{*}{ Paper } & \multirow[b]{2}{*}{$\begin{array}{l}\text { Tools Use for } \\
\text { Analysis }\end{array}$} & \multicolumn{4}{|c|}{ Conclusions Drawn } \\
\hline & & $\begin{array}{c}\text { YES, SPV } \\
\text { Affects the } \\
\text { Urban Milieu }\end{array}$ & $\begin{array}{l}\text { NO, SPV Does } \\
\text { not Affect the } \\
\text { Urban Milieu }\end{array}$ & $\begin{array}{l}\text { Mixed } \\
\text { Results }\end{array}$ & $\begin{array}{c}\text { More Detailed } \\
\text { Studies are } \\
\text { Required }\end{array}$ \\
\hline [26] & $\begin{array}{c}\text { Field } \\
\text { measurements }\end{array}$ & $\sqrt{ }$ & & & $\sqrt{ }$ \\
\hline [27] & Remote sensing & $\sqrt{ }$ & $\sqrt{ }$ & $\sqrt{ }$ & $\sqrt{ }$ \\
\hline [29] & $\begin{array}{l}\text { Simulation } \\
\text { model }\end{array}$ & $\sqrt{ }$ & & & $\sqrt{ }$ \\
\hline [31] & Review & $\sqrt{ }$ & & & $\sqrt{ }$ \\
\hline [33] & $\begin{array}{c}\text { Mathematical } \\
\text { model }\end{array}$ & & & $\sqrt{ }$ & $\sqrt{ }$ \\
\hline [35] & $\begin{array}{c}\text { Mathematical } \\
\text { model }\end{array}$ & $\sqrt{ }$ & & & $\sqrt{ }$ \\
\hline [36] & $\begin{array}{l}\text { Simulation } \\
\text { model }\end{array}$ & & & $\sqrt{ }$ & $\sqrt{ }$ \\
\hline [37] & $\begin{array}{c}\text { Field } \\
\text { measurements }\end{array}$ & $\sqrt{ }$ & & & \\
\hline [38] & $\begin{array}{l}\text { Simulation } \\
\text { model }\end{array}$ & & $\sqrt{ }$ & $\sqrt{ }$ & $\sqrt{ }$ \\
\hline [39] & $\begin{array}{c}\text { Field } \\
\text { measurements }\end{array}$ & & $\sqrt{ }$ & & \\
\hline [40] & $\begin{array}{l}\text { Simulation } \\
\text { model }\end{array}$ & & & & $\sqrt{ }$ \\
\hline [43] & $\begin{array}{l}\text { Simulation } \\
\text { model }\end{array}$ & & $\sqrt{ }$ & & $\sqrt{ }$ \\
\hline$[44]$ & $\begin{array}{l}\text { Simulation } \\
\text { model }\end{array}$ & & $\sqrt{ }$ & $\sqrt{ }$ & $\sqrt{ }$ \\
\hline [45] & $\begin{array}{l}\text { Simulation } \\
\text { model }\end{array}$ & $\sqrt{ }$ & & & \\
\hline$[46]$ & $\begin{array}{l}\text { Simulation } \\
\text { model }\end{array}$ & $\sqrt{ }$ & & & $\sqrt{ }$ \\
\hline [47] & $\begin{array}{l}\text { Simulation } \\
\text { model }\end{array}$ & $\sqrt{ }$ & & & $\sqrt{ }$ \\
\hline
\end{tabular}

The interpretation of all studies was simplified and divided in four parts (Figure 4). A major amount of incidental solar radiation falling on SPV panels ultimately is converted into heat and dissipates in the surrounding environment. The potential outcome of this process is alteration in the thermal environment of the surroundings at the micro-level. As the effects of even $1.5^{\circ} \mathrm{C}$ of increase in the global temperature are seen to be causing catastrophic effects, so a considerable increase in the vicinity of the solar plants will impact the macro-climate of the region. Considering that, we are at a vulnerable stage in climate change with small, insignificant steps inducing unpredictable results. It is understood that the effect of the SPV plants does not happen in isolation, rather it subsequently affects the biodiversity, heat flows, and the wind patterns, to name a few. 


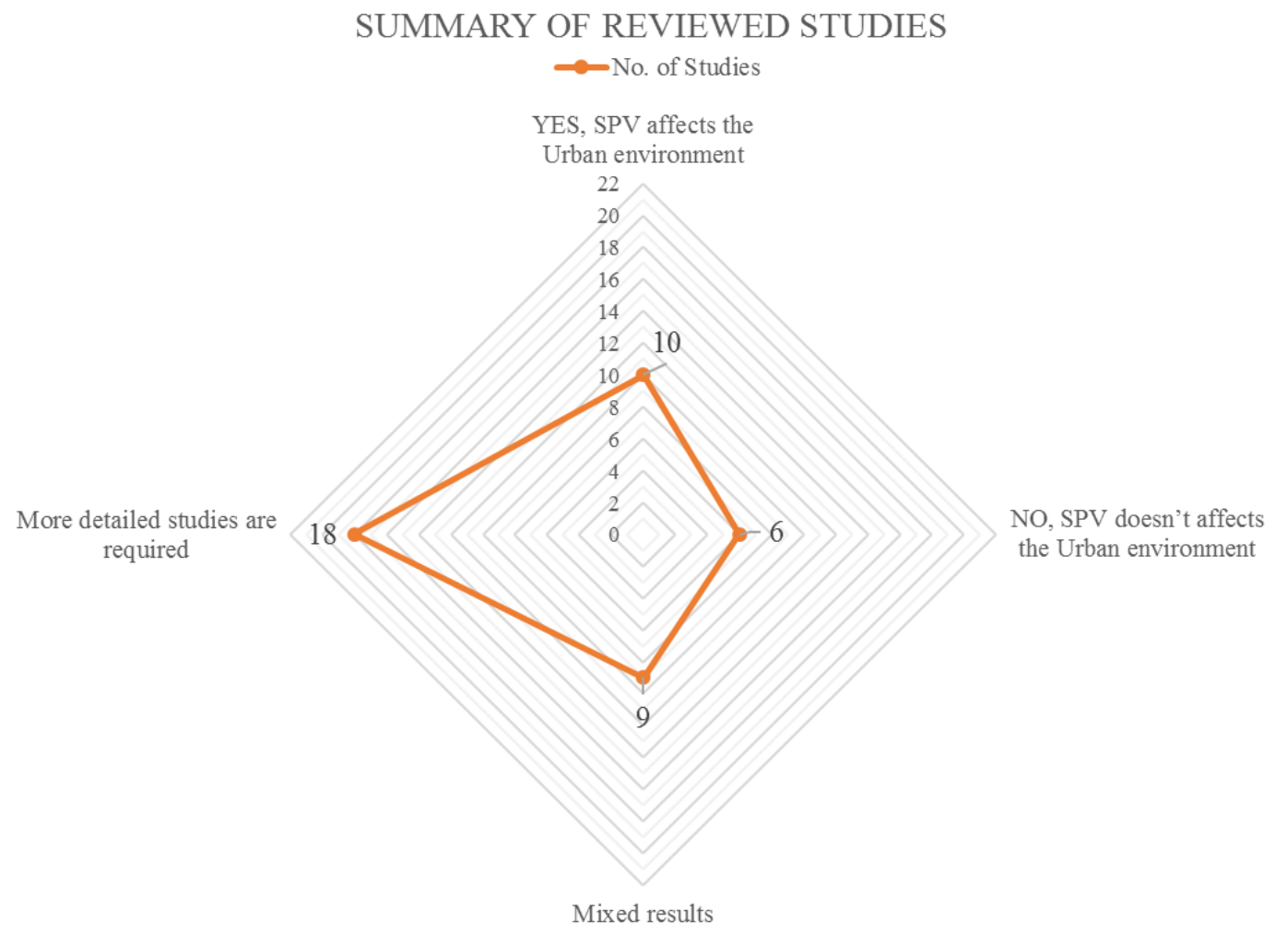

Figure 4. The summary of reviewed studies on the effect of SPV installation on the urban milieu.

Studies have highlighted that SPV installations induce changes in the regional climate but considered them as unavoidable in the era of depleting energy resources and their high emissions. However, in searching for a stopgap solution, knowing the inevitability of the exponential rise of SPV installations on earth is not advised. Apart from the theoretical results, practical study data need to be gathered to inform and convince decision-makers about solar installations in the urban milieu [43]. Although solar farms were found to enhance precipitation in a study by Li et al., it cannot be clearly established that they will always increase precipitation due to albedo changes [47], which underlines the need of specific studies on various sites in different regions.

Out of two field studies on SPV-based UHIs, only one paper has experimented, examined, and claimed the occurrence of the heat island effect due to SPV installations [26]. However, the difficult and expensive yet compulsory task of measuring each component of SPV installation still needs to be done [26]. The comprehensive measurement of both can provide a holistic understanding of the energy exchange between SPV installations and their surroundings [26]. Deploying SPV panels in the urban area without understanding the local climate can alleviate local temperatures and, hence, increase the energy demand [35]. All these studies galvanize the need for in-depth field verification of SPV energy balance to account for the dynamic weather patterns on the microclimatic influences of any region. Moreover, the paper identifies the absence of any single comprehensive study on the interaction of SPV with the UTE. Specifically, there is a need to assess the impacts of smaller-scale wind and solar farms installed at specific locations with the help of advanced global and regional climate models with higher spatial resolutions.

In densely populated countries, the emphasis is on SPV-based energy generation. The different types of land use and building surfaces in the various regions are the evident spaces for the installations in such countries. Broadly, there are two land-use types-agricultural land and barren land-used for SPV installations. Researchers have identified a great potential in terms of energy saving with the use of SPV installations over agricultural land [48], whereas others project them as a potential means to overcome the effect of the harsh climatic conditions such as heat and drought on the crops, 
through reduction of high temperatures and excessive direct radiation [48]. However, their impact on different type of crops is yet to be known. Regardless, it is evident that SPV installations on agricultural land alter its microclimatic conditions [48]. SPV installations over desert land reduce the albedo and soil temperature while consequently increasing the ambient temperature [49]. The former might be beneficial for desert plantations but the effects of the latter are yet to be explored.

Solar photovoltaic technology is continually evolving and it is critical to use panels that are more efficient to inhibit the negative impacts of SPV technology as highlighted by various researchers. Numerous technologies with high conversion efficiency, such as Perovskite and dye-sensitized solar cells, are available that, in conjunction with efficient techniques such as Building Integrated Photovoltaics (BIPV), can be implemented at a larger scale. This can lead to better energy production and less impact on the surroundings, as established through various studies. However, dedicated research is needed to establish this firmly, as highlighted by Pillai et al. in a research on the performance of BIPV in tropical regions, which emphasized that the internal temperatures were higher than the ambient outdoor temperature in BIPV structures [50].

The overall long-term sustainability of SPV installation and operation has been considered debatable in comparison to the other renewable energy sources with respect to the effects on the environment and the humans within it [1]. However, under the scope of local climatic effects, researchers suggest further detailed studies as the results obtained from macro-level observations are either insufficient or inconclusive [2]. Proposed ways to do the same can be (i) field assessment of large scale SPV installations with respect to their surroundings, potentially via remote sensing or thermography; (ii) field-based experiments identifying the complex relations between SPV technology and the surrounding microclimate; (iii) studies about the synergy of SPV technology in a controlled environment for different seasons and climatic zones, potentially via simulation.

SPV technology, being at its developmental stage, provides lot of scope for improvement at the technical and installation levels. In general, BIPV might prove to be an effective technical solution for the problem highlighted and presented in this paper. Nevertheless, the author would recommend site- and region-based specific studies of current SPV installations through on-site data collection. This data could be further used to identify the appropriate technology and technique for proposed SPV installations in a particular region or site. The work demonstrated in the paper is a preliminary step, underlining a need for more detailed observational studies.

Funding: This research did not receive any external funding.

Acknowledgments: I acknowledge the School of Planning and Architecture, Delhi, for providing me the opportunity and resources to conduct this research.

Conflicts of Interest: The author declares no conflict of interest.

\section{Abbreviations}

$\alpha_{\mathrm{pv}} \quad$ Albedo of the upward face of the SPV panel.

$\varepsilon_{\text {pv_f }} \quad$ Emissivity of the upward face of the SPV panel.

$\varepsilon_{\mathrm{pv} \_b} \quad$ Emissivity of the downward face of the SPV panel.

eff $_{\mathrm{pv}} \quad$ Solar conversion efficiency of the SPV panel.

$\mathrm{LW}_{\text {in }}$ Incoming longwave radiation $\left(\mathrm{W} / \mathrm{m}^{2}\right)$.

$\mathrm{LW}_{\text {out }}$ Outgoing longwave radiation $\left(\mathrm{W} / \mathrm{m}^{2}\right)$ (emitted) from surfaces.

$\mathrm{LW}_{\mathrm{t}} \quad$ Trapped longwave radiation $\left(\mathrm{W} / \mathrm{m}^{2}\right)$ between SPV and underlying surface.

$\mathrm{SW}_{\text {in }} \quad$ Incoming shortwave radiation $\left(\mathrm{W} / \mathrm{m}^{2}\right)$.

$\mathrm{SW}_{\text {out }}$ Outgoing shortwave radiation $\left(\mathrm{W} / \mathrm{m}^{2}\right)$ (reflected) from surfaces.

$\mathrm{Q}_{\mathrm{S}} \quad$ Stored thermal heat flux $\left(\mathrm{W} / \mathrm{m}^{2}\right)$ in surfaces.

$\mathrm{Q}_{\mathrm{E}} \quad$ Latent heat flux $\left(\mathrm{W} / \mathrm{m}^{2}\right)$ from vegetation (evapotranspiration) and soil.

$\mathrm{Q}_{\mathrm{A}} \quad$ Anthropogenic heat flux $\left(\mathrm{W} / \mathrm{m}^{2}\right)$ from the SPV panel and other materials/activities.

$\mathrm{Q}_{\mathrm{H}} \quad$ Sensible heat flux $\left(\mathrm{W} / \mathrm{m}^{2}\right)$ from the SPV panel and other surfaces into the atmosphere.

$\mathrm{T}_{\mathrm{pv}} \quad$ Temperature $\left({ }^{\circ} \mathrm{C}\right)$ of the SPV panel. 


\section{References}

1. Phillips, J. Determining the sustainability of large-scale photovoltaic solar power plants. Renew. Sustain. Energy Rev. 2013, 27, 435-444. [CrossRef]

2. Turney, D.; Fthenakis, V. Environmental impacts from the installation and operation of large-scale solar power plants. Renew. Sustain. Energy Rev. 2011, 15, 3261-3270. [CrossRef]

3. Santamouris, M.; Synnefa, A.; Karlessi, T. Using advanced cool materials in the urban built environment to mitigate heat islands and improve thermal comfort conditions. Sol. Energy 2011, 85, 3085-3102. [CrossRef]

4. Armstrong, A.; Waldron, S.; Whitaker, J.; Ostle, N.J. Wind farm and solar park effects on plant-soil carbon cycling: Uncertain impacts of changes in ground-level microclimate. Glob. Chang. Biol. 2014, 20, 1699-1706. [CrossRef]

5. Oke, T.R.; Mills, G.; Christen, A.; Voogt, J.A. Urban Climates; Cambridge University Press: Cambridge, UK, 2017. [CrossRef]

6. Berdahl, P.; Bretz, S.E. Preliminary survey of the solar reflectance of cool roofing materials. Energy Build. 1997. [CrossRef]

7. Xu, M. Development of an Integrated Urban Heat Island Simulation Tool. Ann. Ecol. Environ. Sci. 2017, 1, $27-45$.

8. Lacis, A.A.; Hansen, J.E. A parameterization for the absorption of solar radiation in the earth's atmosphere. J. Atmos. Sci. 1974, 31. [CrossRef]

9. Ohlhorst, C.W.; Vaughn, W.L.; Daryabeigi, K.; Lewis, R.K.; Rodriguez, A.C.; Milhoan, J.D.; Koenig, J.R. Emissivity Results on High Temperature Coatings for Refractory Composite Materials. 2018. Available online: http://hdl.handle.net/2060/20070031768 (accessed on 16 September 2020).

10. Salamanca, F.; Tonse, S.; Menon, S.; Garg, V.; Singh, K.P.; Naja, M.; Fischer, M.L. Top-of-atmosphere radiative cooling with white roofs: Experimental verification and model-based evaluation. Environ. Res. Lett. 2012, 7. [CrossRef]

11. Ostry, M.; Charvat, P. Materials for advanced heat storage in buildings. Procedia Eng. 2013. [CrossRef]

12. Christen, A.; Vogt, R. Energy and radiation balance of a central European City. Int. J. Climatol. 2004. [CrossRef]

13. Muhaisen, A. Investigation of the Thermal Performance of Building Form in the Mediterranean Climate of the Gaza Strip. IUG J. Nat. Stud. 2013, 21, 101-122.

14. Mirzaei, P.A.; Haghighat, F. Approaches to study Urban Heat IslanD-Abilities and limitations. Build. Environ. 2010, 45, 2192-2201. [CrossRef]

15. Bande, L.; Afshari, A.; Al Masri, D.; Jha, M.; Norford, L.; Tsoupos, A.; Marpu, P.; Pasha, Y.; Armstrong, P. Validation of UWG and ENVI-met models in an Abu Dhabi District, based on site measurements. Sustainability 2019, 11, 4378. [CrossRef]

16. Wilson, W. Constructed Climates: A Primer on Urban Environments; University of Chicago Press: Chicago, IL, USA, 2011.

17. Demirezen, E.; Ozden, T.; Akinoglu, B.G. Impacts of a photovoltaic power plant for possible heat island effect. In Proceedings of the 2018 International Conference on Photovoltaic Science and Technologies (PVCon), Ankara, Turkey, 4-6 July 2018; pp. 1-7. [CrossRef]

18. Xu, M.; Bruelisauer, M.; Berger, M. Development of a new urban heat island modeling tool: Kent Vale case study. Procedia Comput. Sci. 2017, 108, 225-234. [CrossRef]

19. Tomlinson, C.J.; Chapman, L.; Thornes, J.E.; Baker, C. Remote sensing land surface temperature for meteorology and climatology: A review. Meteorol. Appl. 2011, 18, 296-306. [CrossRef]

20. US EPA. Reducing Urban Heat Islands: Compendium of Strategies-Urban Heat Island Basics; 2008. Available online: https://www.epa.gov/sites/production/files/2014-06/documents/basicscompendium.pdf (accessed on 16 September 2020).

21. Oke, T.R. The energetic basis of the urban heat island. Q. J. R. Meteorol. Soc. 1982, 108, 1-24. [CrossRef]

22. Blocken, B. Computational Fluid Dynamics for urban physics: Importance, scales, possibilities, limitations and ten tips and tricks towards accurate and reliable simulations. Build. Environ. 2015, 91, 219-245. [CrossRef]

23. Taha, H. The potential for air-temperature impact from large-scale deployment of solar photovoltaic arrays in urban areas. Sol. Energy 2013, 91, 358-367. [CrossRef] 
24. Hu, A.; Levis, S.; Meehl, G.A.; Han, W.; Washington, W.M.; Oleson, K.W.; van Ruijven, B.J.; He, M.; Strand, W.G. Impact of solar panels on global climate. Nat. Clim. Chang. 2016, 6, 290-294. [CrossRef]

25. Edalat, M.M.; Stephen, H. Effects of two utility-scale solar energy plants on land-cover patterns using SMA of Thematic Mapper data. Renew. Sustain. Energy Rev. 2017, 67, 1139-1152. [CrossRef]

26. Barron-Gafford, G.A.; Minor, R.L.; Allen, N.A.; Cronin, A.D.; Brooks, A.E.; Pavao-Zuckerman, M.A. The Photovoltaic Heat Island Effect: Larger solar power plants increase local temperatures. Sci. Rep. 2016, 6, 35070. [CrossRef] [PubMed]

27. Matai, K.; Manchanda, S. LST Mapping of SPV to Gauge Their Influence on Near-Surface Air Temperature of New Delhi City. In Green Buildings and Sustainable Engineering; Springer: Singapore, 2018; pp. 3-24.

28. Burg, B.R.; Ruch, P.; Paredes, S.; Michel, B. Placement and efficiency effects on radiative forcing of solar installations. AIP Conf. Proc. 2015, 1679. [CrossRef]

29. Cortes, A.; Murashita, Y.; Matsuo, T.; Kondo, A.; Shimadera, H.; Inoue, Y. Numerical evaluation of the effect of photovoltaic cell installation on urban thermal environment. Sustain. Cities Soc. 2015. [CrossRef]

30. Armstrong, A.; Ostle, N.J.; Whitaker, J. Solar park microclimate and vegetation management effects on grassland carbon cycling. Environ. Res. Lett. 2016, 11. [CrossRef]

31. Hernandez, R.R.; Easter, S.B.; Murphy-Mariscal, M.L.; Maestre, F.T.; Tavassoli, M.; Allen, E.B.; Barrows, C.W.; Belnap, J.; Ochoa-Hueso, R.; Ravi, S.; et al. Environmental impacts of utility-scale solar energy. Renew. Sustain. Energy Rev. 2014, 29, 766-779. [CrossRef]

32. Sahu, B.K. A study on global solar PV energy developments and policies with special focus on the top ten solar PV power producing countries. Renew. Sustain. Energy Rev. 2015, 43, 621-634. [CrossRef]

33. Nemet, G.F. Net radiative forcing from widespread deployment of photovoltaics. Environ. Sci. Technol. 2009. [CrossRef]

34. Parthasara, S.; Neelamegam, P.; Thilakan, P. Outdoor Performance Characterization of Multi-Crystalline Silicon Solar Module. J. Appl. Sci. 2012, 12, 1953-1959. [CrossRef]

35. Burg, B.R.; Ruch, P.; Paredes, S.; Michel, B. Effects of radiative forcing of building integrated photovoltaic systems in different urban climates. Sol. Energy 2017, 147, 399-405. [CrossRef]

36. Millstein, D.; Menon, S. Regional climate consequences of large-scale cool roof and photovoltaic array deployment. Environ. Res. Lett. 2011, 6. [CrossRef]

37. Pham, J.V.; Baniassadi, A.; Brown, K.E.; Heusinger, J.; Sailor, D.J. Comparing photovoltaic and reflective shade surfaces in the urban environment: Effects on surface sensible heat flux and pedestrian thermal comfort. Urban Clim. 2019, 29. [CrossRef]

38. Genchi, Y.; Ishisaki, M.; Ohashi, Y.; Kikegawa, Y.; Takahashi, H.; Inaba, A. Impacts of large-scale photovoltaic panel installation on the heat island effect in Tokyo. In Proceedings of the Fifth Conference on the Urban Climate, Łódź, Poland, 1-5 September 2003; pp. 1-4.

39. Fthenakis, V.; Yu, Y. Analysis of the potential for a heat island effect in large solar farms. In Proceedings of the 2013 IEEE 39th Photovoltaic Specialists Conference (PVSC), Tampa, FL, USA, 16-21 June 2013; pp. 3362-3366. [CrossRef]

40. Scherba, A.; Sailor, D.J.; Rosenstiel, T.N.; Wamser, C.C. Modeling impacts of roof reflectivity, integrated photovoltaic panels and green roof systems on sensible heat flux into the urban environment. Build. Environ. 2011, 46, 2542-2551. [CrossRef]

41. Chemisana, D.; Lamnatou, C. Photovoltaic-green roofs: An experimental evaluation of system performance. Appl. Energy 2014, 119, 246-256. [CrossRef]

42. Efthymiou, C.; Santamouris, M.; Kolokotsa, D.; Koras, A. Development and testing of photovoltaic pavement for heat island mitigation. Sol. Energy 2016, 130, 148-160. [CrossRef]

43. Masson, V.; Bonhomme, M.; Salagnac, J.-L.; Briottet, X.; Lemonsu, A. Solar panels reduce both global warming and urban heat island. Front. Environ. Sci. 2014, 2, 1-10. [CrossRef]

44. Salamanca, F.; Georgescu, M.; Mahalov, A.; Moustaoui, M.; Martilli, A. Citywide Impacts of Cool Roof and Rooftop Solar Photovoltaic Deployment on Near-Surface Air Temperature and Cooling Energy Demand. Bound. Layer Meteorol. 2016, 161, 203-221. [CrossRef]

45. Heusinger, J.; Broadbent, A.M.; Sailor, D.J.; Georgescu, M. Introduction, evaluation and application of an energy balance model for photovoltaic modules. Sol. Energy 2020, 195, 382-395. [CrossRef]

46. Chang, R.; Luo, Y.; Zhu, R. Simulated local climatic impacts of large-scale photovoltaics over the barren area of Qinghai, China. Renew. Energy 2020, 145, 478-489. [CrossRef] 
47. Li, Y.; Kalnay, E.; Motesharrei, S.; Rivas, J.; Kucharski, F.; Kirk-Davidoff, D.; Bach, E.; Zeng, N. Climate model shows large-scale wind and solar farms in the Sahara increase rain and vegetation. Science 2018, 361, 1019-1022. [CrossRef]

48. Weselek, A.; Ehmann, A.; Zikeli, S.; Lewandowski, I.; Schindele, S.; Högy, P. Agrophotovoltaic systems: Applications, challenges, and opportunities. A review. Agron. Sustain. Dev. 2019, 39. [CrossRef]

49. Yang, L.; Gao, X.; Lv, F.; Hui, X.; Ma, L.; Hou, X. Study on the local climatic effects of large photovoltaic solar farms in desert areas. Sol. Energy 2017, 144, 244-253. [CrossRef]

50. Pillai, R.; Aaditya, G.; Mani, M.; Ramamurthy, P. Cell (module) temperature regulated performance of a building integrated photovoltaic system in tropical conditions. Renew. Energy 2014, 72, 140-148. [CrossRef]

(C) 2020 by the author. Licensee MDPI, Basel, Switzerland. This article is an open access article distributed under the terms and conditions of the Creative Commons Attribution (CC BY) license (http://creativecommons.org/licenses/by/4.0/). 